\title{
Determination of Additional Willingness to Pay for Socially Responsible Technical Products Using Discrete Choice Analysis
}

\author{
Florian V. Haase ${ }^{1}$, Maria Kohlmeyer ${ }^{1}$, Beatrice Rich ${ }^{1} \&$ Ralf Woll $^{1}$ \\ ${ }^{1}$ Chair of Quality Management, Brandenburg University of Technology Cottbus-Senftenberg, Cottbus, Germany \\ Correspondence: Florian V. Haase, Chair of Quality Management, Brandenburg University of Technology \\ Cottbus-Senftenberg, Siemens-Halske-Ring 14, 03046 Cottbus, Germany. Tel: 49-355-693-941. E-mail: \\ florianvincent.haase@b-tu.de
}

Received: December 1, 2015

Accepted: December 20, 2015 Online Published: February 25, 2016

doi:10.5539/jms.v6n1p45

URL: http://dx.doi.org/10.5539/jms.v6n1p45

\begin{abstract}
Previous studies examined additional willingness to pay for socially responsible primary goods. However, technical products have not been considered. Therefore, the purpose of this study is to estimate additional willingness to pay for socially responsible technical products. Within an overview of given methods for measuring willingness to pay, the discrete choice analysis was applied to this study. As technical products, computer mice were chosen exemplary, since there is a partially fair mouse available. It was found that two of three fair labeled mice have a negative willingness to pay. Only consumers of the fair produced and labeled mouse has a positive willingness to pay. The consumers pay perhaps more attention to the aspect of social responsibility, if presented brands are comparatively unknown. In this connection, consumers allocate a higher value to social responsibility.
\end{abstract}

Keywords: additional willingness to pay, socially responsible products, sustainable management, discrete choice analysis

\section{Introduction}

Social responsibility is a concept of an unclear framework, which depends on political objectives and social orders (van den Daele, 1993). From the marketing theoretical perspective, socially responsible products have to be competitive. Furthermore, they have to provide comparable usefulness with other products for customers. On that condition and if in the whole process people and their social community are free of personal and social hazards, this is referred to a socially responsible product (Peyer \& Balderjahn, 2007).

Socially responsible products can be assigned to the sustainable consumption. In the broad sense this sustainable consumption covers the decrease of socio-ecological problems compared to the conventional consumption (Peyer \& Balderjahn, 2007). According to the approach of sustainable development the sustainable consumption is based on three components: economic, ecological and social. The economic component can be related to the egoistic and ethical form of consumption. That is why the promotion of sustainable consumption is based on frame conditions, institutions and individual factors. The expected need satisfaction and the perceived costs are main factors regarding the individual purchase decision (Balderjahn, 2013). These two factors are relevant for producers of sustainable products. The producer has to identify the requirements and has to design his product in consideration of an acceptable additional charge; that in the end the purchase decision will be made for the sustainable option. Fair procured products, which can be assigned to the social consumption and which focus on humane labor conditions, achieve double-digit annual growth (Fairtrade International, 2014).

In general, the willingness to pay rises with the product benefit. An additional ethical value would increase the willingness as well. Personal factors can be crucial factors for the price level (Balderjahn, 2013). Nevertheless, the willingness to pay for socially responsible products is shown in different studies (Balderjahn \& Peyer, 2012; Peyer \& Balderjahn, 2007). Though the studies apply to primary goods. For this reason, the focus is on the following question: How is the willingness of customers to pay an additional price for a technical product which is produced in compliance with standards of social aspects? 


\section{Determination of the Additional Willingness to Pay}

\subsection{Basics of the Additional Willingness to Pay}

The willingness to pay is the fundamental readiness of a costumer to pay a maximum price for a specific performance in a future purchase situation (Diller, 2008). This approach is based on the reservation price. The willingness to pay more is the difference between the customer's willingness to pay and the market price of a considered good. Consumers attribute the price with a negative benefit. To initialize a purchase decision, the negative benefit has to be compensated by positive attributes of the product (Balderjahn \& Peyer, 2012; Peyer \& Balderjahn, 2007). Consumers are willing to pay more if they notice an additional use of a service or a product. This additional use can be shown by customer's perceived quality or by a symbolic effect.

The methods to record the willingness to pay more can be classified regarding different aspects. There are stated preferences and revealed preferences. Furthermore, it has to be decided whether the individual or aggregate willingness should be recorded. Another possible classification is the direct and indirect method of collecting data (Balderjahn, 2014; Balderjahn \& Peyer 2012; Peyer, 2014; Peyer \& Balderjahn, 2007; Telser, 2002; Voeth $\&$ Niederauer, 2008). In the literature an ideal method for the determination of the willingness to pay does not exist. All these methods are based on heterogeneous assumptions with different strengthen and weaknesses (Peyer, 2014; Voeth \& Niederauer, 2008).

\subsection{Methods to Determine the Willingness to Pay}

\subsubsection{Market Data}

The deduction of the willingness to pay is based on investigated purchase and decision data on an aggregated level. Demand functions can be derived from investigated sales volume and different prices using analytical regression models (Niederauer, 2009). The analysis of real purchase data, which are connected to high validity and less survey effort, are advantages of this method. However, it has disadvantages too. The collected data of the customer behavior are based on predetermined prices. In the data are only consumers included who bought the product to a demanded price. Potential customers are not considered because the market price is higher than their individual willingness to pay (Peyer, 2014; Balderjahn, 2014). The use of historical market data implicates a restricted validity for future reactions of consumers to the market situation. A meaningful application of this method for new products is excluded (Gieseking, 2009; Simon \& Faßnacht, 2009).

\subsubsection{Expert Judgments}

Interviewing experts is a fast and cost-saving method to measure the willingness to pay more. Management consultants, retailer and employees of a company are possible experts. Due to its close cooperation with consumers and their marketability experts have a high knowledge regarding customer needs, new trends and the predominant competition. In the literature, the use of expert judgments for measuring the willingness to pay more is not recommended because of the low objectivity and validity (Breidert, 2006; Peyer, 2014; Simon \& Faßnacht, 2009).

\subsubsection{Experiments}

Price experiments serve the collection of data from observations with systematic variation. Test persons get products with different prices in real or simulated purchase situations. Their reactions were recorded. Field trials, laboratory experiments and direct marketing, as a special form, are types of price experiments. In field trials, the effects of varied prices to the behavior of the test persons are examined under real purchase condition and otherwise unchanged factors. This method has a high validity because the test persons do not know that they are a part of an experiment (Simon \& Faßnacht, 2009).

During laboratory experiments, a simulated purchase situation will be created. Influences, which are not to be analyzed, are maintained constant. The test persons get a fix sum of money, which they can spend to shown competitive products. The low costs and expenditure of time are advantages over field trails. Due to the simulated purchase situation the validity of the results is limited. The test persons know that they are a part of an experiment. It is not guaranteed that the tests persons purchase behavior is the same like in a real situation. Furthermore, there exists a possible distortion of the results through the effect of the received money (Gieseking, 2009; Simon \& Faßnacht, 2009).

\subsubsection{Contingent Valuation}

The contingent valuation method investigates the instantaneous willingness to pay for a specific product based on an individual level. The simplest form, the open-ended approach, asks the test persons the question, how much they would be willing to pay more or at most for a detailed described product or an explicit product feature 
(Hartmann, 2014). To show products with different prices and ask the test persons to express their purchase intention is the closed-ended-approach (Balderjahn, 2014; Niederauer, 2009; Völckner, 2006).

Advantages like the easy and fast type of data collection, the application for new as well as existing products and the low costs are opposed by certain disadvantages. The open question wording is not part of a typical purchase environment, which could lead to an excessive demand for the study participant. Especially for complex or innovative products it is hard for the test persons to quantify their personal benefit (Breidert, 2006; Peyer, 2014; Völckner; 2006; Voeth, 2008). Because of the price-oriented way of phrasing the questions, the attention of the study participant is drawn towards the price, which implies an artificially increased price sensitivity. The result is a low willingness to pay which does not match the actual buying behavior of the test persons. (Balderjahn, 2014; Niederauer, 2009; Völckner, 2006). Further problems particularly for studies with ethical questions are possible distorting effects through the influence of social desirability. Study participants state a higher willingness to pay than their actual willingness in order to meet the supposed social norm (Balderjahn \& Peyer, 2012; Diller, 2008). The resulting differences between stated and actual willingness to pay is based on the hypothetical decision situation (Völckner, 2006). Because of the mentioned points, the validity of the direct price review should be critically examined. (Balderjahn, 2014; Peyer, 2014; Völckner, 2006).

\subsubsection{Auctions}

Auctions can be used for the acquisition of individual willingness to pay. Compared to other methods test persons buy the product at an auction instead of just stating a purchase intention. Therefore, auctions are assigned to incentive compatible procedures. The seller does not define the purchase price because it is determined by the price bids of the participants (Balderjahn, 2014). Vickrey-auctions are particularly suitable to determine the price acceptance (Simon \& Faßnacht, 2009; Skiera \& Spann, 2014). Due to the auction situation, rationally acting test persons have the incentive to bid only at the level of their actual willingness to pay in order to avoid benefit deficits by false statements. The person whose bid is accepted pays a price equal to no more than his willingness to pay (Simon \& Faßnacht, 2009; Skiera \& Spann, 2014; Vickrey, 1961; Völckner, 2006). A disadvantage of the Vickrey-auction is the unrealistic purchase situation because the test persons are competing against each other for a rare good. Empirical studies show that auction participants bid partly above their willingness to pay just to get the acceptance of a bid. Another problem is the increased price awareness, which is induced by the direct price quotation (Breidert, 2006; Völckner, 2006). For example, there was examined the effects of social responsibility labelling and brand on willingness to pay for apparel (Hustvedt \& Bernard, 2010).

\subsubsection{Lotteries}

A further method for the detection of the willingness to pay in form of purchasing bids is represented by lotteries. This approach was developed by Becker, De Groot and Marschak (1964). The data collection is carried out in two steps: first, the study participants state their willingness to pay for a product directly. Afterward, one price will be drawn from the price range of all bids. If the test person's willingness to pay is above the chosen price, they are obligated to buy the product at the determined price. If the chosen price is above their willingness to pay, they are excluded from purchase. As with the Vickery-auction, there is an incentive for the test persons to state their true willingness of pay. This concludes in high validity. In contrast to the Vickery-auction, the study participants are not competing against each other so that an outbidding is not possible. Increased price awareness and an artificial purchase situation have adverse effects on the measurement of willingness to pay (Balderjahn \& Peyer, 2007; Breidert, 2006; Sattler \& Nitschke, 2003).

\subsubsection{Conjoint Analysis}

The conjoint analysis is a common instrument in market research for the measurement of individual benefit structures (Diller, 2008). Luce and Tukey developed the method of conjoint analysis for the application in mathematical and psychological research (Luce \& Tukey, 1964). In the early 70s first used the conjoint analysis for market research (Green \& Rao, 1971). In the conjoint analysis, products and services are understood as a combination of single characteristics. It is set on the assumption that the overall benefit of a concept consists of partial utility values of certain characteristics. The study participants are not asked to state their willingness to pay directly but to evaluate single product profiles. The price will be included in the conjoint design and constitutes only one of many product characteristics. Therefore, increased price sensitivity is not possible. Especially because of the decompositional nature, the validity is rated very highly (Balderjahn, 2014; Böhler \& Scigliano, 2009).

In the traditional conjoint analysis, the test persons are asked either to rank the stimuli according to their preference or to evaluate them using a ranking scale. The ranking requires that study participants carry out a deliberated consideration between the characteristics in which case the ideal as well as the least favored 
characteristic can be determined (Backhaus et al., 2011; Klein, 2002; Otter, 2001). Advantages of the survey using a rating instead of a ranking are the simple application and the extraction of interval scaled data that lead to a more precise determination of gradations in the evaluation of the product profiles (Klein, 2002; Otter, 2001). A disadvantage of the traditional conjoint analysis is the missing information whether the test person would also buy the product or service for the given price (Breidert, 2006).

The adaptive conjoint analysis features an individual adjustment of the valuation of stimuli to the test persons. Furthermore, it combines compositional and decompositional forms of preference query. The data collection is carried out in two steps, of which the first part represents an indication of characteristic preferences. Afterward, study participants state in a paired comparison which stimuli they prefer. The characteristics for a paired comparison are selected using the previously retrieved results. Advantages of the adaptive conjoint analysis are on one hand the possibility of regarding a high number of characteristics and features and on the other hand the fast assessment of the collected data. The advantage of excluding an increased price sensitivity, which is given using the traditional conjoint analysis, is also given using the adaptive conjoint analysis, due to the direct interrogation of preferences (Herrmann et al., 2009; Peyer, 2014).

The choice-based conjoint analysis examines discrete choices. Therefore, the choice-based conjoint analysis is associated with the discrete analysis models rather than with the conjoint analysis. Using the choice-based conjoint analysis, the consumer's willingness to pay can only be determined on an aggregated level. The choice-based conjoint analysis combines the approaches of conjoint analysis in the form of presentation and the discrete choice analysis in form of data collection and analysis (Balderjahn, 2014; Balderjahn \& Peyer, 2009; Cohen, 1997). The choice-based conjoint analysis is a common instrument of determining the willingness to pay (Balderjahn \& Peyer, 2009).

\section{Determination of the Additional Willingness to Pay for Socially Responsible Technical Products}

\subsection{Methodology}

For this study, the discrete choice analysis based on the works of McFadden was chosen (Ben-Akiva \& Lerman, 1985; McFadden, 1990) because of several advantages in comparison to other methods of measuring the willingness to pay. On the one hand, an excessive demand of the test persons concerning their responsiveness is avoided because of the realistic decision-making situation.

The use of an alternative will be accompanied by an observed choosing action of the consumer; that they do not have to specify the use themselves. In this process, personal as well as product-specific characteristics that influence the consumers' decision are being considered. Uncontrollable influences are included in the stochastic benefit component which leads to an overall consideration. Another positive effect is caused by embedding the price in holistically described product profiles which eliminates an increased price consciousness of the test persons. Also, in contrast to the conjoint analysis, interactions between two characteristics like brands or prices are being considered. The discrete choice analysis can only be applied for supply situations with a relatively small number of product characteristics (Balderjahn, 2014).

Strictly speaking, the method which is used for this study is the choice-based conjoint analysis because the product profiles regarded in the supply situations are shown in form of a conjoint-design. However, due to the methodological and statistical background associated with the discrete choice analysis, the term discrete choice analysis will be used further on in this study. The basis of the discrete choice analysis is four assumptions and two hypotheses which are essential for the collection and analysis of the data, for more information see (Balderjahn, 1993; Hahn, 1997; Peyer \& Balderjahn, 2007).

\subsection{Study Design}

\subsubsection{Choice of Product}

For the choice of a suitable product two conditions have to be complied. On the one hand, it has to be a technical product and on the other hand, the aspect of social responsibility has to be relevant for the product. Especially in the electronics industry socially responsible productions tend to be an exception. For most products the manufacturing takes place in low-wage countries with poor working conditions partly hazardous to health. Therefore, most products of this industry fulfill both conditions (Electronics Watch, 2013).

The discrete choice analysis does not presume the involvement of a real socially responsible product in order to detect the willingness to pay. However, the higher reference to reality is an advantage. Two product options can be considered which are at least partly produced in a fair way and also already available on the market: There is a smart phone called Fairphone by the company Fairphone and a computer mouse by NagerIT called Die Faire Maus. The manufacturing of both products is socially more responsible in comparison to other companies. 
Nevertheless, both companies point out that the complexity of the supply chain makes a hundred percent fair production almost impossible and both products are continuously developed to be more socially responsible (Hartmann, 2014; Nager IT, 2012a; Nager IT, 2012b).

Table 1. Features of a computer mouse

\begin{tabular}{ll}
\hline technical & economical \\
\hline connection & price \\
cable length & warranty \\
number of buttons & \\
resolution & \\
Laser/LED & \\
\hline
\end{tabular}

For this study a fair computer mouse was chosen because compared to a smart phone the mouse has fewer characteristics that can influence the purchase decision of the consumer. The aim of the analysis is the identification of the willingness to pay for technical products regarding the social responsibility, which is why other influences will be minimized. The relatively low price of basic computer mice is another advantage because of the assumptions that consumers are more willing to pay a higher price for cheaper products than for expensive products (Nager IT, 2012b). Possible Characteristics that could be relevant for the consumer purchasing a computer mouse are listed in Table 1.

The choice situation for the test persons consists of three computer mice and a non-purchase-option. The features and characteristics of the fair produced mouse are the default for the choice of other products in order to minimize influences outside of the price and the social responsibility.

\subsubsection{Design}

The social responsibility of a product is mainly a trust-characteristic for the consumer because it cannot be judged neither before nor after the purchase due to a lack of information. Quality labels of independent organizations and established brands can make such characteristics accessible for the consumer and help to guide them. Labels of this kind are not very common in the electronic industry. The test seal TCO Certified of the independent institution TCO Development certifies sustainable products of the IT-industry. The testing of the products is carried out checking both ecological and social criteria. The original intention behind the introduction of the seal was to mark sustainable and specifically low-radiation IT-products (TCO Development, 2012; TCO Development, 2015). For the purpose of this study, however, the seal is insufficient for two reasons. It is only of little popularity and the test persons could misinterpret the meaning of the seal.

For this reason, a known fair label was chosen to illustrate the social responsibility. The fair label includes the observance of human rights, fair working conditions, fair wages and environmental aspects. The label is awarded to goods from the food industry, flowers, sport balls, cotton textiles and cosmetics and is therefore basically not transferable to technical products. Because of the predominant advantages the seal was nevertheless used for this study. The pictorial representation of the social responsibility offers the possibility that the test persons do not focus explicitly on this characteristic which minimizes distorting effects of socially desirable answers. Due to the high popularity and the international validity, the seal fulfills for this study the purpose of marking products as socially acceptable.

The decision-making situation for the test persons consisted of holistically described product profiles. An advantage of the discrete choice analysis in comparison to the conjoint analysis is the assumption of a representative utility function which is why only one decision per test person had to be recorded (Peyer \& Balderjahn, 2007). Since consumers usually have several purchase alternatives to choose from which they compare with each other and select the utility-maximizing option for them, this survey situation corresponds to a real purchase situation. Due to the preselection of the computer mice only the characteristics price, brand/design and social responsibility are regarded during the decision-making process. There was an annotation included, stating that the remaining characteristics do not differ between the product versions. The range of the given market prices of $€ 12.90$ to $€ 32.90$ was divided into three price segments:

- lower price segment: $€ 12.90$ to $€ 19.63$,

- medium price segment: $€ 19.64$ to $€ 26.27$ and

- upper price segment: $€ 26.28$ to $€ 32.90$ 
For the particular price segments, specific product prices were estimated using a random algorithm. Afterward, the prices were assigned to the products. Every decision-making situation consisted of one computer mouse from the lower, the medium and the upper price segment as well as a non-purchase-option. This approach ensures the required large range for estimating the utility parameter needed for the discrete choice analysis. The product combinations differ only in terms of their prices and which product is labeled with a known fair label. Every test person was consequently assigned to an individual product-price-scenario (Balderjahn, 1993; Balderjahn, 2014; Peyer \& Balderjahn, 2007). Every third mouse of a variant was sealed.

\subsection{Data Collection}

The survey was conducted face-to-face, while participants were students. This is not a representative population, but satisfies the assumption in discrete choice analysis of homogeneous preferences. It is assumed that the surveyed students have similar behavior when purchasing a technically simple computer mouse. 195 people were interviewed. 11 were excluded since they are no students. 124 male and 60 female students participated in the survey. In addition to the decision to choose a product, the participants are asked about purchase behavior and certification of socially responsible products:

- knowledge of the used fair label,

- assessment of personal purchasing behavior for fair labeled products,

- assessment of personal trust in fair labels,

- detection of the label in product selection and

- awareness of the fair produced computer mouse.

The second part of the survey is handed out to the participants after the first part was completed. Accordingly, distorting effects of socially correct answers could be excluded (Peyer \& Balderjahn, 2007).

\subsection{Evaluation of the Empirical Study}

\subsubsection{Descriptive Analysis}

The distribution of participants decisions to choose a mouse varies, see Table 2. 32.1\% decided for a fair labeled mouse. The awareness of the used fair label is $80.4 \%$. So the application of this label seems to be suitable for the study. In contrast, $4.9 \%$ of participants indicated that they know the fair produced mouse. The fair produced mouse is selected by $33.1 \%$ of participants who know the used fair label. The trust of participants in social labels are mediocre. In more than three quarters of the cases the participants have rarely or uncommonly purchased fair produced products before. The used label is noticed by $73.4 \%$ of the participants in product choice.

Table 2. Distribution of the product choice

\begin{tabular}{ll}
\hline option & choice in \% \\
\hline Fair produced mouse & 8 \\
mouse $A$ & 29 \\
mouse $B$ & 46 \\
non-purchase & 17 \\
\hline
\end{tabular}

Male participants chose to $75 \%$ a mouse without label, while female's choice was equally distributed between products with and without labels (55\% without label). The fair produced mouse is selected more often with than without a label. $34.2 \%$ of the participants chose a mouse with a label and $65.8 \%$ without a label, if they have bought at least a socially responsible certified product before.

\subsubsection{Evaluation of the Discrete Choice Analysis}

The various effects on product decision were differentiated in product-related and personal factors, see Figure. 1. With respect to the product, the brand, the used fair label, past purchases of socially responsible products, the reputation of the label and price are included. The sex was specified as a personal factor influencing the decision. A model parameter is estimated for each factor. The general deterministic utility component is described as (Peyer \& Balderjahn, 2007):

$$
v_{i k}=\alpha_{0}+\alpha_{\mathrm{f}} \cdot \text { label }+\alpha_{p} \cdot \text { price }+\alpha_{g} \cdot \text { label }_{\text {purchase_behaviour }}+\alpha_{b} \cdot \text { label }_{\text {awareness }}+\beta \cdot \operatorname{sex}
$$

where

- $v_{\text {ik }}=$ deterministic utility component, 
- $\alpha_{0}=$ parameter of the alternative specific constant (brand),

- $\alpha_{\mathrm{f}}=$ parameter for the utility of the used fair label,

- $\alpha_{p}=$ parameter for the utility of the price,

- $\alpha_{g}=$ parameter for the influence of past purchases of products with the used fair label on the current choice decision of an alternative,

- $\alpha_{b}=$ parameter for the influence of awareness of the used fair label on the current choice decision of an alternative and

- $\beta=$ parameter for the influence of gender on the choice decision.

The McFadden pseudo- $\mathrm{R}^{2}$ is 0.411 , which corresponds to a variance explained by $41.1 \%$. The target value is approximately 1.0, whereas values between 0.2 and 0.4 can already be interpreted as a good adjustment (McFadden, 1979; Schendera, 2008). Accordingly, the value of 0.411 shows a very good model fit. The evaluation of the discrete choice analysis was performed with SPSS software. The non-purchase option is the reference category for the estimation of the model parameters. Table 3 contains a summary of the results of the model estimation. For mouse $A$ the deterministic utility component is:

$v_{i k}=-19,649+2,552 \cdot$ label $+2,310 \cdot$ price $+3,128 \cdot$ label $_{\text {purchase_behaviour }}-1,612 \cdot$ label $_{\text {awareness }}+1,815 \cdot \mathrm{sex}$

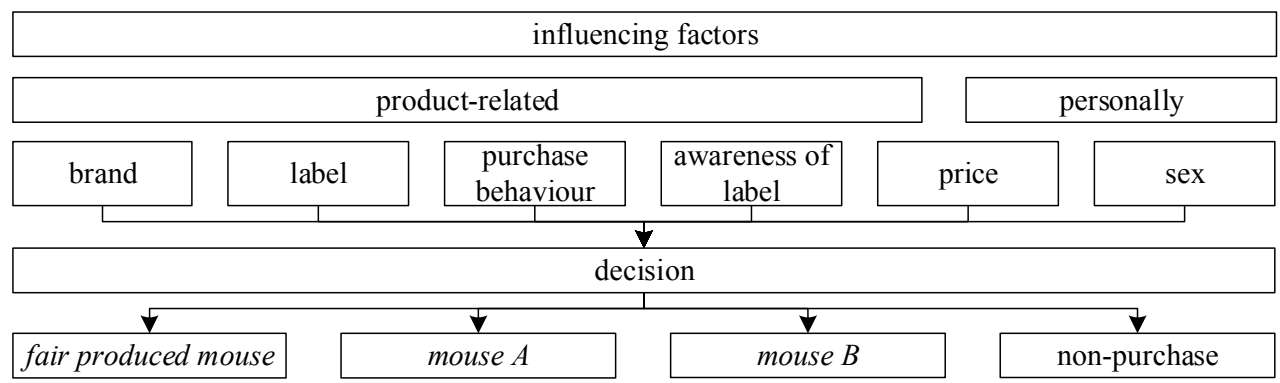

Figure 1. Product-related and personal influencing factors the selection of a computer mouse with reference to Peyer \& Balderjahn (2007)

The used fair label has a positive regression coefficient $B$ for all mice. Therefore, the label favors a decision for a fair labeled mouse. The odds ratio $\operatorname{Exp}(B)$ describes this fact by indicating the probability of an event in relation to the opposite. The odds ratio is calculated in relation to the reference category by multinomial logistic regression (Peyer \& Balderjahn, 2007; Schendera, 2008). It has very high values since a non-purchase option was specified as reference category. That means, there are much more participants who decide to purchase a mouse than those who chose the non-purchase option. For example, related to the non-purchase option, mouse $B$ with label was selected 13 times more often.

Generally, increasing prices reduces consumer utility and that will decrease the product's probability of selection. But a higher price may also implicit a higher quality. The overall utility of alternatives increases and consumers are willing to pay a higher price which can describe the odds ratio $\operatorname{Exp}(B)>1$. Furthermore, purchases of fair labeled products in the past have a positive selection effect on all computer mice in contrast to the awareness of the used fair label. 
Table 3. Results of the discrete choice analysis

\begin{tabular}{|c|c|c|c|c|c|c|}
\hline \multirow[t]{2}{*}{ brand $^{\mathrm{a}}$} & & \multirow{2}{*}{$\begin{array}{l}\text { regression } \\
\text { coefficient B }\end{array}$} & \multirow[t]{2}{*}{ significance } & \multirow[t]{2}{*}{$\operatorname{Exp}(B)$} & \multicolumn{2}{|c|}{$95 \%$ confidence interval for $\operatorname{Exp}(B)$} \\
\hline & & & & & lower limit & upper limit \\
\hline fair produced & constant term & -20.715 & 0.987 & & & \\
\hline \multirow[t]{5}{*}{ mouse } & price & 2.271 & 0.000 & 9.692 & 8.632 & 10.882 \\
\hline & label & 3.691 & 0.998 & 40.097 & 0.000 &.$^{b}$ \\
\hline & $\operatorname{sex}$ & 2.424 & 0.998 & 11.293 & 0.000 &.$^{b}$ \\
\hline & label $_{\text {purchase behaviour }}$ & 2.788 & 0.003 & 16.248 & 2.666 & 99.022 \\
\hline & label $_{\text {awareness }}$ & -2.294 & 0.999 & 0.101 & 0.000 & $b^{b}$ \\
\hline \multirow[t]{6}{*}{ mouse $A$} & constant term & -19.649 & 0.987 & & & \\
\hline & price & 2.310 & 0.000 & 10.079 & 9.452 & 10.748 \\
\hline & label & 2.552 & 0.999 & 12.837 & 0.000 &.$^{b}$ \\
\hline & $\operatorname{sex}$ & 1.815 & 0.999 & 6.144 & 0.000 &.$^{b}$ \\
\hline & label $1_{\text {purchase_behaviour }}$ & 3.128 & 0.000 & 22.819 & 8.306 & 62.692 \\
\hline & label $_{\text {awareness }}$ & -1.621 & 0.999 & 0.198 & 0.000 &. \\
\hline \multirow[t]{6}{*}{ mouse $B$} & constant term & -19.575 & 0.987 & & & \\
\hline & price & 2.322 & . & 10.197 & 10.197 & 10.197 \\
\hline & label & 2.634 & 0.999 & 13.926 & 0.000 & $\mathrm{~b}^{\mathrm{b}}$ \\
\hline & $\operatorname{sex}$ & 1.076 & 0.999 & 2.933 & 0.000 &.$^{b}$ \\
\hline & label $1_{\text {purchase_behaviour }}$ & 2.139 & . & 8.488 & 8.488 & 8.488 \\
\hline & label $_{\text {awareness }}$ & -1.299 & 0.999 & 0.273 & 0.000 &.${ }^{\mathrm{b}}$ \\
\hline
\end{tabular}

${ }^{a}$ The reference category is non-purchase.

${ }^{\mathrm{b}}$ A floating point error has occurred in the calculation.

\subsubsection{Determination of Willingness to Pay}

The price-response function is used to determine the willingness to pay out of the collected data. Product choices are described as a function of price. The first step is to define different price ranges (Balderjahn, 1994). The market price of the cheapest mouse (mouse B) is $€ 12.90$, the fair produced mouse costs $€ 32.90$. The difference of $€ 20$ is divided into five individual price ranges:

- $€ 12.90$ to $€ 16.90$,

- $€ 16.91$ to $€ 20.90$

- $€ 20.91$ to $€ 24.90$,

- $€ 24.91$ to $€ 28.90$ and

- $€ 28.91$ to $€ 32.90$.

The price ranges are used to see, how different prices of each mouse determine the consumer's choice. The price ranges are further divided into labeled and non-labeled mice. The mice are assigned to price ranges and the relative frequency can be calculated, see Table 4 (Voeth \& Niederauer, 2008). Consequently, the market shares are determined for each mouse, labeled and non-labeled.

Table 4. Proportions of the decision for mice with and without label

\begin{tabular}{|c|c|c|c|c|}
\hline \multirow{2}{*}{$\begin{array}{l}\text { mouse } A \\
\text { price range }[€]\end{array}$} & \multicolumn{2}{|c|}{ without label } & \multicolumn{2}{|c|}{ with label } \\
\hline & quantity & relative frequency & quantity & relative frequency \\
\hline $12.90-16.90$ & 17 & 0.2 & 7 & 0.082 \\
\hline $16.91-20.90$ & 13 & 0.153 & 10 & 0.118 \\
\hline $20.91-24.90$ & 13 & 0.153 & 4 & 0.047 \\
\hline $24.91-28.90$ & 4 & 0.047 & 6 & 0.071 \\
\hline $28.91-32.90$ & 7 & 0.082 & 4 & 0.047 \\
\hline total & 54 & 0.635 & 31 & 0.365 \\
\hline mouse B & \multicolumn{2}{|c|}{ without label } & \multicolumn{2}{|c|}{ with label } \\
\hline price range $[€]$ & quantity & relative frequency & quantity & relative frequency \\
\hline $12.90-16.90$ & 6 & 0.111 & 7 & 0.130 \\
\hline $16.91-20.90$ & 11 & 0.204 & 4 & 0.074 \\
\hline $20.91-24.90$ & 5 & 0.093 & 2 & 0.037 \\
\hline $24.91-28.90$ & 8 & 0.148 & 4 & 0.074 \\
\hline $28.91-32.90$ & 5 & 0.093 & 2 & 0.037 \\
\hline total & 35 & 0.648 & 19 & 0.352 \\
\hline
\end{tabular}




\begin{tabular}{lllll}
\hline fair produced mouse & without label & & with label \\
\hline price range [€] & quantity & relative frequency & quantity & relative frequency \\
\hline $12.90-16.90$ & 1 & 0.071 & 4 & 0.286 \\
$16.91-20.90$ & 3 & 0.214 & 1 & 0.071 \\
$20.91-24.90$ & 0 & 0 & 2 & 1 \\
$24.91-28.90$ & 1 & 0.071 & 1 & 0.143 \\
$28.91-32.90$ & 0 & 0 & 9 & 0.071 \\
total & 5 & 0.357 & & 0.071 \\
\hline
\end{tabular}

The fair produced mouse with label has a higher market share than the non-labeled one. The other two mice achieve higher values without label. Doing a regression of the observed frequencies on the associated prices shows the price-response functions (Balderjahn, 1994). For this purpose, the average prices within every price range are used: $€ 14.90, € 18.90, € 22.90, € 26.90$, and $€ 30.90$. The best data matching is achieved by using a quadratic regression, which can be explained in content. The consumer's willingness to pay is higher in the low price segment than in the middle segment. The upper price segment includes mainly price inelastic consumers who pay attention to product quality (Peyer \& Balderjahn, 2007).

Figure 2 shows the probability for mouse $A$ with and without label of being selected by a participant. Overall, there is a lower willingness to pay for the fair labeled mouse. A price of $€ 23.50$ results in a relative market share of $7.5 \%$ for a fair labeled mouse $A$, whereas the same result would be achieved at the price of $€ 29.25$ without label. The additional price willingness is defined by the two mice's price difference. Therefore, consumers would pay $€ 5.75$ more for a computer mouse $A$ without label.

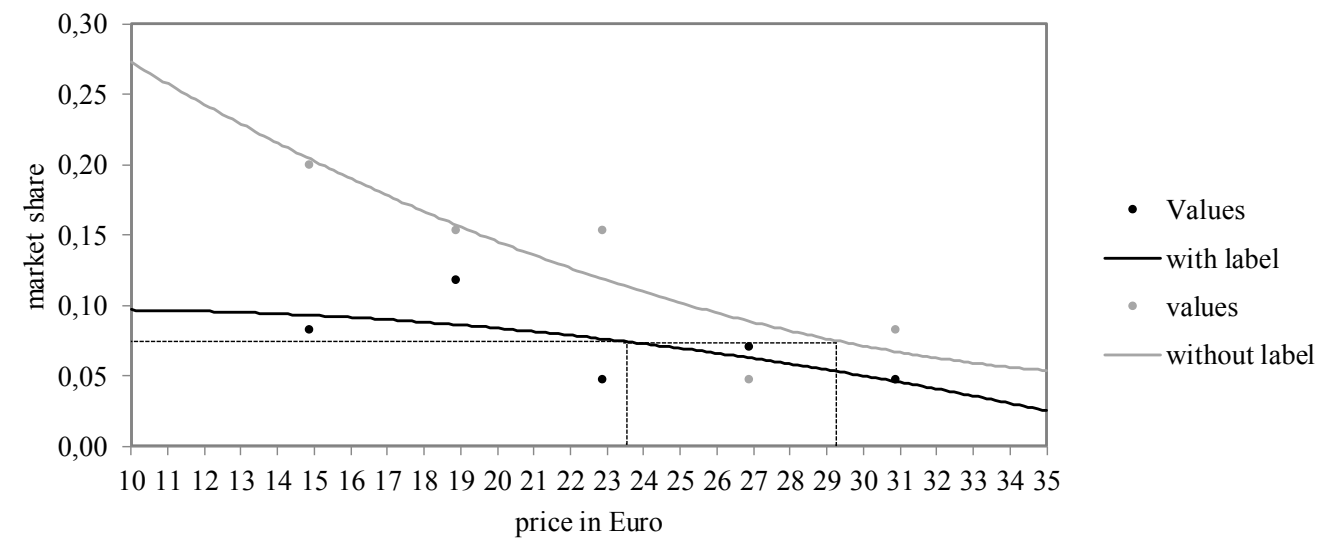

Figure 2. Market share of mouse $A$ with and without label

The model for mouse $B$ generates a higher relative market share for socially responsible products in the lower and in the upper price segment, see Figure 3. A relative market share of $15 \%$ can be achieved at a price of $€$ 20.25 with label and at a price of $€ 13$ without label. Accordingly, consumers would pay $€ 7.25$ more for a computer mouse $B$ without label. 


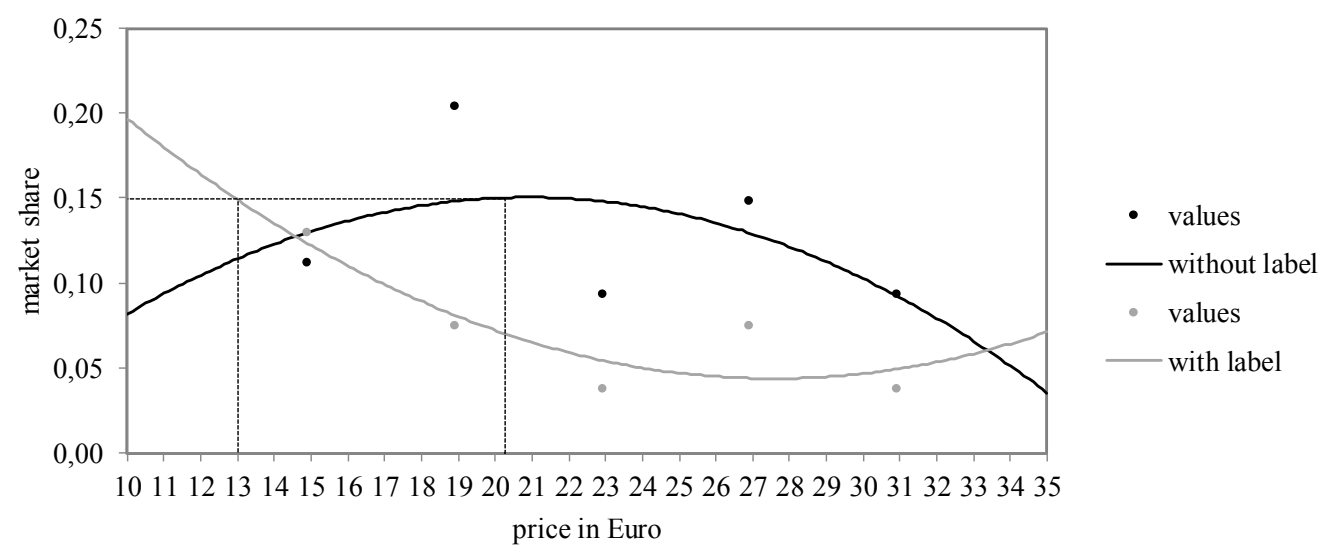

Figure 3. Market share of mouse B with and without label

In case of the fair produced mouse, there is a positive additional willingness to pay, see Figure. 4. A price of $€$ 21.05 for fair labeled mouse results in a market share of $11.25 \%$ while the mouse without label has to have a price of $€ 17.70$. Thus, consumers would pay $€ 3.35$ more for a socially responsible mouse.

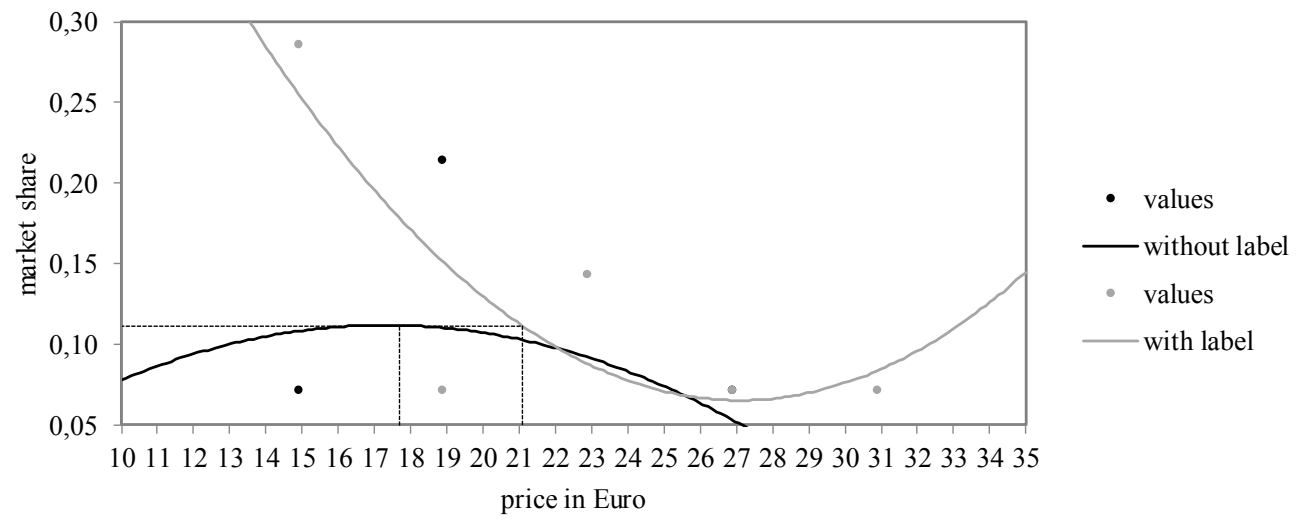

Figure 4. Market share of fair produced mouse with and without label

The negative willingness to pay for mouse $A$ and mouse $B$ shows that social responsibility does not influence the purchase decision positively. Other features, such as brand or design, represent relevant decision criteria for consumers. While for unknown brands such as fair produced mouse there is maybe a consumer decision due to characteristics and specifications instead of brand's quality associated. As a result, consumers will highlight and perceive the aspect of social responsibility to greater extent.

\subsubsection{Assessment of the Results in Comparison to Socially Responsible Primary Goods}

Several studies found a higher willingness to pay for primary goods with Fairtrade label, namely coffee (Arnot et al, 2006; Carlsson et al., 2010; de Pelsmacker et al., 2005; Galarraga \& Markandya, 2004; Hertel et al. 2009; Koppel \& Schulze, 2013; Loureiro \& Lotade, 2005; Trudel \& Cotte, 2009), bananas (Rousu \& Corrigan, 2008), orange juice (Peyer \& Balderjahn, 2007), chocolate (Didier \& Lucie, 2008; Rousseau, 2015; Rousu \& Corrigan, 2008; Vecchio \& Annunziata, 2015), wine (Balderjahn \& Peyer, 2012) and rice (Balderjahn \& Peyer, 2012). Castaldo et al. analyzed the effect of the Fairtrade label in general. One result is that consumers who trust in the label, also have a higher willingness to pay for certified products (Castaldo et al., 2009). Moreover, the consumer's willingness to pay for social responsibility is higher than the willingness to pay for environmental responsibility (Tully \& Winer, 2014).

The varying results of an additional willingness to pay for primary goods and this study may have different reasons. Consumers basically imply a higher quality if products comply with production standards. But the certification of primary goods is more known to them as the certification of technical products. Especially since fair labeled food is available in almost every discounter. A familiarity of $80.4 \%$ for the used fair label and just 
$4.9 \%$ for the fair produced mouse supports this assumption.

Apart from this, technical products are characterized by complex supply chains and being compared to primary goods, a socially responsible production is more difficult. Companies that set themselves the goal of creating a completely fair product, such as NagerIT or Fairphone, are not able to offer complete socially responsible products. Also information asymmetries may have a negative impact on the purchase decision. In addition, resignations of consumers may occur, since there are no completely fair alternatives available. Criticizing reviews of the previously fairest alternatives to traditional engineering products (Hartmann, 2014; Social Startups Media, 2014) affect the reputation of socially responsible, technical products adversely.

\section{Conclusion}

Methods for determining additional willingness to pay all have advantages and disadvantages. In particular, a high price sensitivity among the participants can lead to distorted results. The conjoint analysis and discrete choice analysis are common procedures. While the conjoint analysis is characterized by a product ranking or rating by participants, participants of a discrete choice analysis make fictitious purchase decisions. Both methods apply the price in a holistically described product profile and an increasing price sensitivity can be excluded. Since one decision per participant is sufficient to the assumption of a representative utility function the discrete choice analysis is used. While an assessment of multiple choice situations with no varying product characteristics would not correspond to the real purchase situation.

The key findings of this study are that the used fair label as a symbol of social responsibility has no significant influence on the participant's choice and that only the fair produced mouse implies an additional willingness to pay. Consequently, consumers are usually not willing to pay a higher price for social responsibility regarding technical products. However, the willingness to pay more for the fair produced mouse could be interpreted as consumers assigning unknown brands greater benefit to social responsibility. Other characteristics, such as brand image, are not considered as much. The different designs of computer mice have to be assessed. In particular, the simple appearance of the fair produced mouse could have a detrimental effect on the decision of the participants.

In this study, generally a positive additional willingness to pay for socially responsible technical products in contrast to primary goods was not determined. On one hand, consumers possibly assign the socially responsible alternative among primary goods a higher benefit because a higher quality is implied. On the other hand, information asymmetries exist. The complexity of the supply chain is higher. Even companies with the aim of producing a fair alternative to conventional products did not produce a completely fair product so far. Increasing sales of socially responsible products show that the market for socially responsible alternatives exists. But a greater exchange between the consumer and supplier has to happen in order to translate this insight into technical products.

\section{Acknowledgments}

This work was supported by the Brandenburg Ministry of Science, Research and Culture (MWFK) as part of the International Graduate School at Brandenburg University of Technology Cottbus-Senftenberg.

\section{References}

Arnot, C., Boxall, P. C., \& Cash, S. B. (2006). Do ethical consumers care about price? A revealed preference analysis of fair trade coffee purchases. Canadian Journal of Agricultural Economics/Revue canadienne d'agroeconomie, 54(4), 555-565. http://dx.doi.org/10.1111/j.1744-7976.2006.00066.x

Backhaus, K, Erichson, B., Plinke, W., \& Weiber, R. (2011). Multivariate Analysemethoden: Eine anwendungsorientierte Einführung. Berlin, Germany: Springer. http://dx.doi.org/10.1007/978-3-642-16491-0

Balderjahn, I. (1993). Marktreaktionen von Konsumenten: Ein theoretisch-methodisches Konzept zur Analyse der Wirkung marketingpolitischer Instrumente. Berlin, Germany: Duncker \& Humblot. http://dx.doi.org/10.3790/978-3-428-47649-7

Balderjahn, I. (1994). Der Einsatz der Conjoint-Analyse zur empirischen Bestimmung von Preisresponsefunktionen. Marketing: Zeitschrift für Forschung und Praxis, 16(1), 12-20.

Balderjahn, I. (2013). Nachhaltiges Management und Konsumverhalten. Konstanz, Germany: UVK.

Balderjahn, I. (2014). Erfassung der Preisbereitschaft. In H. Diller \& A. Herrmann (Eds.), Handbuch Preispolitik (pp. 387-404). Wiesbaden, Germany: Gabler.

Balderjahn, I., \& Peyer, M. (2009). Choice-Based Conjointanalyse. In D. Baier \& M. Brusch (Eds.), 
Conjointanalyse (pp. 129-146). Berlin, Germany: Springer. http://dx.doi.org/10.1007/978-3-642-00754-5_9

Balderjahn, I., \& Peyer, M. (2012). Das Bewusstsein für fairen Konsum: Konzeptualisierung, Messung und Wirkung. Betriebswirtschaft, 72(4), 343-364.

Becker, G. M., DeGroot, M. H., \& Marschak, J. (1964). Measuring utility by a single-response sequential method. Behavioral Science, 9(3), 226-232. http://dx.doi.org/10.1002/bs.3830090304

Ben-Akiva, M., \& Lerman, S. R. (1985). Discrete choice analysis-Theory and application to travel demand. Cambridge, United States, MIT Press.

Böhler, H., \& Scigliano, D. (2009). Traditionelle Conjointanalyse. In D. Baier \& M. Brusch (Eds.), Conjointanalyse (pp. 101-112). Berlin, Germany: Springer. http://dx.doi.org/10.1007/978-3-642-00754-5_7

Breidert, C. (2006). Estimation of Willingness-to-Pay: Theory, Measurement, Application. Wiesbaden, Germany: Deutscher Universitäts-Verlag.

Carlsson, F., García, J. H., \& Löfgren, Å. (2010). Conformity and the demand for environmental goods. Environmental and resource economics, 47(3), 407-421. http://dx.doi.org/10.1007/s10640-010-9385-2

Castaldo, S. et al. (2009), The missing link between corporate social responsibility and consumer trust: The case of fair trade products. Journal of Business Ethics, 84(1), 1-15. http://dx.doi.org/10.1007/s10551-008-9669-4

Cohen, S. H. (1997). CBCA marries the best of conjoint and discrete choice models. Marketing Research, 9(1), 12-17.

de Pelsmacker, P., Driesen, L., \& Rayp, G. (2005). Do consumers care about ethics? Willingness to pay for fair$\begin{array}{lllll}\text { trade } \quad \text { offee. Journal of consumer } & \text { 36fairs, }\end{array}$ http://dx.doi.org/10.1111/j.1745-6606.2005.00019.x

Didier, T., \& Lucie, S. (2008). Measuring consumer's willingness to pay for organic and Fair Trade products. $\begin{array}{lllll}\text { International Journal of } & \text { Consumer } & \text { Studies, } & 32(5), & \text { 479-490. }\end{array}$ http://dx.doi.org/10.1111/j.1470-6431.2008.00714.x

Diller, H. (2008). Preispolitik. Stuttgart, Germany: Kohlhammer.

Electronics Watch. (2013). Die Elektronikbranche. Retrieved September 11, 2015, from http://electronicswatch.org/de/die-elektronikbranche_2937

Fairtrade International. (2014). Annual Report 2013-14. Retrieved February 16, 2015, from www.fairtrade.net/fileadmin/user_upload/content/2009/resources/2013-14_AnnualReport_FairtradeIntl_we b.pdf

Galarraga, I., \& Markandya, A. (2004). Economic techniques to estimate the demand for sustainable products: a case study for fair trade and organic coffee in the United Kingdon. Economia Agraria y Recursos Naturales, (7), 109-134.

Gieseking, T. (2009). Gewinnoptimale Preisbestimmung in werbefinanzierten Märkten: Analyse der Präferenzdaten von Inserenten und Rezipienten einer Finanzzeitschrift. Wiesbaden, Germany: Gabler. http://dx.doi.org/10.1007/978-3-8349-8408-1

Green, P. E., \& Rao, V. R. (1971). Conjoint measurement for quantifying judgmental data. Journal of Marketing research, 355-363. http://dx.doi.org/10.2307/3149575

Hahn, C. (1997). Conjoint- und Discrete-Choice-Analyse als Verfahren zur Abbildung von Präferenzstrukturen und Produktauswahlentscheidungen: Ein theoretischer und computergestützter empirischer Vergleich. Münster, Germany: Lit.

Hartmann, K. (2014). Fairer geht's noch. enorm-Magazin, 2, 30-33.

Herrmann, A., Huber, F., \& Regier, S. (2009). Adaptive Conjointanalyse. In D. Baier \& M. Brusch (Eds.), Conjointanalyse (pp. 113-127). Berlin, Germany: Springer. http://dx.doi.org/10.1007/978-3-642-00754-5_8

Hertel, S., Scruggs, L., \& Heidkamp, C. P. (2009). Human rights and public opinion: From attitudes to action. Political Science Quarterly, 124(3), 443-459. http://dx.doi.org/10.1002/j.1538-165X.2009.tb00655.x

Hustvedt, G., \& Bernard, C. (2010). Effects of social responsibility labelling and brand on willingness to pay for apparel. International Journal of Consumer Studies, 34(6), 619-626. http://dx.doi.org/10.1111/j.1470-6431.2010.00870.x

Klein, M. (2002). Die Conjoint-Analyse: Eine Einführung in das Verfahren mit einem Ausblick auf mögliche 
sozialwissenschaftliche Anwendungen. ZA-Information, (50), 7-45.

Koppel, H., \& Schulze, G. G. (2013). The Importance of the Indirect Transfer Mechanism for Consumer Willingness to Pay for Fair Trade Products: Evidence from a Natural Field Experiment. Journal of Consumer Policy, 36(4), 369-387. http://dx.doi.org/10.1007/s10603-013-9234-0

Loureiro, M. L., \& Lotade, J. (2005). Do fair trade and eco-labels in coffee wake up the consumer conscience? Ecological Economics, 53(1), 129-138. http://dx.doi.org/j.ecolecon.2004.11.002

Luce, R. D., \& Tukey, J. W. (1964). Simultaneous conjoint measurement: A new type of fundamental $\begin{array}{lllll}\text { measurement. Journal of mathematical psyology, } & 1(1), & 1-27 .\end{array}$ http://dx.doi.org/10.1016/0022-2496(64)90015-X

McFadden, D. (1979). Quantitative Methods for Analysing Travel Behaviour of Individuals. In D. A. Hensher \& P. R. Stopher (Eds.), Behavioural travel modelling (pp. 279-318). London: Croom Helm.

McFadden, D. (1990). Econometric Models of Prohabilistic Choice. In C. F. Manski \& D. McFadden (Eds.), Structural analysis of discrete data with econometric applications (pp. 198-272). Cambridge: MIT Press.

Nager IT (2012a). Faire Elektronik. Retrieved September 11, 2015, from https://www.nager-it.de/projekt

Nager IT (2012b). FAQ/Häufige Fragen. Retrieved September 11, 2015 from https://www.nager-it.de/informationen/faq

Niederauer, C. (2009). Messung von Zahlungsbereitschaften bei industriellen Dienstleistungen. Wiesbaden, Germany: Gabler. http://dx.doi.org/10.1007/978-3-8349-8352-7

Otter, T. (2001). Conjointanalyse zur Messung und Erklärung von Markenwert. Doctoral dissertation, WU Vienna University of Economics and Business.

Peyer, M. (2014). Faires Konsumentenverhalten: Analyse von Einflussfaktoren auf die Kaufentscheidung und Zahlungsbereitschaft für faire Produkte. Hamburg, Germany: Kovač.

Peyer, M., \& Balderjahn, I. (2007). Zahlungsbereitschaft für sozialverträgliche Produkte. Jahrbuch der Absatz-und Verbrauchsforschung, 53(3), 267-288.

Rousseau, S. (2015). The role of organic and fair trade labels when choosing chocolate. Food Quality and Preference, 44, 92-100. http://dx.doi.org/10.1016/j.foodqual.2015.04.002

Rousu, M. C., \& Corrigan, J. R. (2008). Estimating the welfare loss to consumers when food labels do not adequately inform: An application to fair trade certification. Journal of Agricultural \& Food Industrial Organization, 6(1). http://dx.doi.org/10.2202/1542-0485.1212

Sattler, H., \& Nitschke, T. (2003). Ein empirischer Vergleich von Instrumenten zur Erhebung von Zahlungsbereitschaften. Zeitschrift für betriebswirtschaftliche Forschung, 55(2), 364-381.

Schendera, C. F. G. (2008). Regressionsanalyse mit SPSS. München, Germany: Oldenbourg. $\mathrm{http}: / / \mathrm{dx}$.doi.org/10.1524/9783486710625

Simon, H., \& Faßnacht, M. (2009). Preismanagement: Strategie, Analyse, Entscheidung, Umsetzung. Wiesbaden, Germany: Gabler.

Skiera, B., \& Spann, M. (2014). Auktionen. In H. Diller \& A. Herrmann (Eds.), Handbuch Preispolitik (pp. 622-641). Wiesbaden, Germany: Gabler.

Social Startups Media. (2014). Von wegen Fairphone. Retrieved September 8, 2015, from http://www.social-startups.de/fairphone/

TCO Development. (2012). TCO Certified. Retrieved August 7, 2015, from http://tcodevelopment.de/tco-certified/

TCO Development. (2015). Über TCO Development. Retrieved August 7, 2015, from http://tcodevelopment.de/uber-tco-development/

Telser, H. (2002). Nutzenmessung im Gesundheitswesen: Die Methode der Discrete-Choice-Experimente. Hamburg, Germany: Kovač.

Trudel, R., \& Cotte, J. (2009). Does it pay to be good. MIT Sloan Management Review, 50(2), 61-68.

Tully, S. M., \& Winer, R. S. (2014). The role of the beneficiary in willingness to pay for socially responsible products: A meta-analysis. Journal of Retailing, 90(2), 255-274. http://dx.doi.org/10.1016/j.jretai.2014.03.004 
van den Daele, W. (1993). Sozialverträglichkeit und Umweltverträglichkeit. Inhaltliche Mindeststandards und Verfahren bei der Beurteilung neuer Technik. Pvs, 2(93), 219-284.

Vecchio, R., \& Annunziata, A. (2015). Willingness-to-pay for sustainability-labelled chocolate: an experimental $\begin{array}{llll}\text { auction approach. Journal of Cleaner Production, 86, 335-342. } & \text { 86 }\end{array}$ http://dx.doi.org/10.1016/j.jclepro.2014.08.006

Vickrey, W. (1961). Counterspeculation, auctions, and competitive sealed tenders. The Journal of finance, 16(1), 8-37. http://dx.doi.org/10.1111/j.1540-6261.1961.tb02789.x

Voeth, M., \& Niederauer, C. (2008). Ermittlung von Preisbereitschaften und Preisabsatzfunktionen. In A. Herrmann, C. Homburg, \& M. Klarmann (Eds.), Handbuch Marktforschung (pp. 1073-1095). Wiesbaden, Germany: Gabler.

Völckner, F. (2006). Methoden zur Messung individueller Zahlungsbereitschaften: Ein Überblick zum State of the Art. Journal für Betriebswirtschaft, 56(1), 33-60. http://dx.doi.org/10.1007/s11301-006-0002-y

\section{Copyrights}

Copyright for this article is retained by the author(s), with first publication rights granted to the journal.

This is an open-access article distributed under the terms and conditions of the Creative Commons Attribution license (http://creativecommons.org/licenses/by/3.0/). 